\title{
Cerdas dan Bijak Bergaul di Era Digital
}

\author{
Asmaul Husna', Yuhdi Fahrimal'2, Akmal Saputra ${ }^{3,}$ Cut Asmaul Husna ${ }^{4}$ \\ 12Jurusan Ilmu Komunikasi, Universitas Teuku Umar \\ Email : asmaulhusna@utu.ac.id \\ Email : yuhdifahrimal@utu.ac.id \\ 3Jurusan Sosiologi, Universitas Teuku Umar \\ Email : akmalsaputera@utu.ac.id \\ 4Jurusan Ilmu Administrasi Negara, Universitas Teuku Umar \\ Email : cutasmaulhusna@gmail.com
}

Submitted: 17 November 2019 Revised: 10 Desember 2019 Accepted: 12 Desember 2019

\begin{abstract}
Teenagers who are aware of opportunities and challenges in the future need a lot of learning to help them develop their potential so that they feel proud of themselves so that they want to learn and practice with their peers. In line with the rapid development of technology, teenagers are required to be able to follow the flow of social media development. Nowadays, social media has become one of the important factors to get the latest information, a means of socializing and building relationships, even being able to change one's perspective in responding to something that is happening. In addition, social media facilitated by the internet has now even become a means the most massive use by teenagers because they are considered to have no time and space restrictions. But of course not all teenagers are aware of the opportunities and potential they have for themselves. Therefore, they still need guidance and direction from adults to find role models as a reference for the formation of their identity, foster trust and acceptance of themselves, develop interpersonal communication skills and mingle with peers. Provision of knowledge and understanding of personal branding can certainly help them prepare and improve their abilities, have bright ideas with thinking out of the box methods, have good communication skills by utilizing social media and the internet wisely so that they have competitiveness and sensitivity to the challenges of the times.
\end{abstract}

Keyword: Internet, Communication, Personal Branding, Teenagers.

\begin{abstract}
Abstrak
Remaja yang sadar akan peluang dan tantangan di masa depan memerlukan banyak pembelajaran guna membantu mereka dalam mengembangkan potensi yang dimilikinya supaya mereka merasa bangga atas dirinya sehingga ia mau belajar dan berlatih bersama teman-teman sebayanya. Sejalan dengan perkembangan teknologi yang begitu pesat, remaja dituntut untuk mampu mengikuti arus perkembangan media sosial. Saat ini, media sosial telah menjadi salah satu faktor penting untuk mendapatkan berbagai informasi terkini, sarana bersosialisasi dan menjalin relasi, bahkan mampu merubah cara pandang seseorang dalam menyikapi sesuatu hal yang sedang terjadi. Selain itu,media sosial yang terfasilitasi oleh internet kini bahkan telah menjadi sarana paling massif digunakan oleh para remaja karena dianggap tidak memiliki batasan ruang dan waktu. Namun tentu saja tidak semua remaja sadar akan peluang dan potensi yang ia miliki atas dirinya. Oleh itu,mereka masih memerlukan bimbingan dan arahan dari para orang dewasa untuk menemukan role model sebagai acuan pembentukan identitasnya, menumbuhkan kepercayaan dan penerimaan atas dirinya, mengembangkan ketrampilan komunikasi interpersonal dan bergaul bersama teman sebayanya. Pemberian pengetahuan dan pemahaman mengenai personal branding ini tentunya dapat membantu mereka dalam menyiapkan dan meningkatkan kemampuan diri, memiliki gagasan cemerlang dengan metode thinking out of the box, memiliki kemampuan berkomunikasi yang baik dengan memanfaatkan media sosial dan internet secara bijak supaya mempunyai daya saing serta kepekaan terhadap tantangan perkembangan zaman.
\end{abstract}

Kata Kunci: Internet, Komunikasi, Personal Branding, Remaja 


\section{PENDAHULUAN}

Tidak mudah

untuk mendefinisikan kata remaja secara tepat, karena ada begitu banyak sudut pandang yang dapat digunakan dalam mengartikannya. Kata "remaja" sendiri berasal dari bahasa Latin adolescene yang berarti to grow atau to grow maturity (Jahja, 2011). Banyak pula yang mendefinisikan remaja sebagai masa transisi perkembangan antara masa kanak-kanak dan dewasa yang pada umumnya dimulai pada usia 12 atau 13 tahun dan berakhir pada usia akhir belasan tahun atau awal dua puluh tahun. Sedangkan Anna Freud berpendapat bahwa pada masa remaja terjadi proses perkembangan meliputi perubahanperubahan yang berhubungan dengan perkembangan psikoseksual, dan juga terjadi perubahan dalam hubungan dengan orangtua dan cita-cita mereka, dimana pembentukan cita-cita merupakan proses pembentukan orientasi masa depan (Wirawan, 2002).

Masa remaja merupakan segmen penting dalam kehidupan yang penting dalam siklus perkembangan individu, dan merupakan masa transisi yang dapat diarahkan kepada perkembangan masa dewasa yang sehat. Untuk dapat melakukan sosialisasi dengan baik, remaja harus menjalankan tugas-tugas perkembangan pada usinya dengan baik. Apabila tugas pekembangan sosial ini dapat dilakukan dengan baik, remaja tidak akan mengalami kesulitan dalam kehidupan sosialnya serta akan membawa kebahagiaan dan kesuksesan dalam menuntaskan tugas perkembangan untuk fase-fase berikutnya. Sebaliknya, manakala remaja gagal menjalankan tugas-tugas perkembangannya akan membawa akibat negatif dalam kehidupan sosial fase-fase berikutnya, menyebabkan ketidakbahagiaan pada remaja yang bersangkutan, menimbulkan penolakan masyarakat, dan kesulitan-kesulitan dalam menuntaskan tugas-tugas perkembangan berikutnya.

Menurut Havighurst dalam Putro (2017) remaja setidaknya memiliki lima tugas penting diantaranya (1) Mengembangkan kecakapan intelektual dan konsepkonsep tentang kehidupan bermasyarakat; (2) Belajar memiliki peranan sosial dengan teman sebaya; (3) Mencapai kebebasan dari ketergantungan terhadap orang tua; (4) Mempersiapkan diri untuk menentukan suatu pekerjaan yang sesuai dengan bakat dan kesanggupannya; (5) Mendapatkan penilaian bahwa dirinya mampu bersikap tepat sesuai dengan pandangan ilmiah. 
Mengingat

tugas-tugas

perkembangan tersebut sangat kompleks dan relatif berat bagi remaja, maka untuk dapat melaksanakan tugas-tugas tersebut dengan baik remaja masih sangat membutuhkan bimbingan dan pengarahan supaya dapat mengambil langkah yang tepat sesuai dengan kondisinya. Di samping itu, remaja masih mempunyai kebutuhan-kebutuhan yang tentu saja menuntut pemenuhan secepatnya sesuai darah mudanya yang bergejolak. Kebutuhan-kebutuhan tersebut, menurut Edward yang meliputi (1) kebutuhan untuk mencapai sesuatu, (2) kebutuhan akan rasa superior, ingin menonjol, ingin terkenal, (3) kebutuhan untuk mendapatkan penghargaan, (4) kebutuhan akan keteraturan, (5) kebutuhan akan adanya kebebasan untuk menentukan sikap sesuai dengan kehendaknya, (6) kebutuhan untuk menciptakan hubungan persahabatan, (7) adanya keinginan ikut berempati, (8) kebutuhan mencari bantuan dan simpati, (9) keinginan menguasai tetapi tidak ingin dikuasai, (10) menganggap diri sendiri rendah, (11) adanya kesediaan untuk membantu orang lain, (12) kebutuhan adanya variasi dalam kehidupan, (13) adanya keuletan dalam melaksanakan tugas, (14) kebutuhan untuk betgaul dengan lawan jenis, dan (15) adanya sikap suka mengkritik orang lain (Agriati, 2008).

Berdasarkan pemaparan tersebut, terlihat jelas bahwa menjadi remaja tentu bukanlah identitas yang biasa-biasa saja. Remaja dengan semangat dan tenaga yang masih berapi-api memiliki tanggung jawab dan memikul harapan yang cukup besar untuk dirinya, masyarakat dan peradaban. Di masa depan, remaja akan menjadi calon pemimpin perubahan maka diharapkan pada saat nanti ia menjadi pengganti generasi pendahulunya ia dituntut untuk mapan dan mampu merubah kondisi sosial yang telah ada menjadi lebih baik. Remaja dengan tantangan zamannya, harus mampu mengembangkan kemampuan diri, memiliki gagasan cemerlang, pemikiran-pemikiran kreatif dengan metode thinking out of the box yang inovatif, serta memiliki kemampuan berkomunikasi yang baik dan harus dapat memanfaatkan kemajuan internet dengan bijak.

Remaja yang sadar dan akan peluang dan tantangan masa depan memerlukan pembelajaran guna mengembangkan fitrah dan potensi dasar yang telah dimiliki agar mereka merasa senang dan bangga atas dirinya sendiri sehingga ia mau belajar dan berlatih bersama teman- 
teman sebayanya. Dalam perkembangan teknologi yang begitu pesat, remaja tidak dapat mengelakkan kemajuan perkembangan media sosial. Media sosial menjadi faktor utama untuk mendapatkan informasi terkini, sarana bersosialisasi dan menjalin relasi, bahkan mampu merubah cara pandang seseorang dalam menyikapi sesuatu yang sedang terjadi.

Seakan telah manampikkan faktor tatap muka, media sosial yang terfasilitasi oleh internet kini bahkan telah menjadi sarana sosialisasi dan menjalin relasi yang paling massif digunakan oleh para remaja karena dianggap tidak memiliki batasan ruang dan waktu. Pergeseran pola interaksi dan sosialisasi ini bahkan mendorong beberapa remaja mulai menjadikan media sosial mereka sebagai sarana bisnis online yang mampu mendulang jutaan rupiah dalam waktu singkat. Mereka menciptakan konten yang menarik serta konsisten melalui visual, audio, maupun tulisan yang tujuannya untuk membangun personal branding guna menarik minat pengiklan dan membangun jaringan yang lebih luas.

Personal branding inilah yang harus disadari dengan benar oleh para remaja, karena hal ini merupakan senjata penting bagi mereka guna bersaing di era digital seperti sekarang ini. Pola interaksi dan bergaul di sosial media haruslah mereka sesuaikan dengan personal branding seperti apa yang hendak mereka bangun. Pemilihan konten dan konteks tentu juga harus mulai diperhatikan dan diselaraskan. Namun tentu saja tidak semua remaja sadar akan peluang dan potensi yang ia miliki atas dirinya. Mereka masih memerlukan bimbingan dan arahan dari orang dewasa guna menemukan role model sebagai acuan pembentukan identitasnya, menumbuhkan kepercayaan dan penerimaan atas dirinya, mengembangkan ketrampilan komunikasi interpersonal dan bergaul dengan teman sebaya, baik secara individual maupun kelompok.

Adapun tujuan pelaksanaan kegiatan pengabdian masyarakat yang berjudul Sosialisasi Cerdas dan Bijak Bergaul di Era Digital ini adalah meningkatkan dan mengembangkan pemahaman para remaja peserta Youth Camp SOS Children's Village Regional Sumatera di Desa Taruna Meulaboh mengenai peluang dan potensi dasar yang mereka miliki agar senantiasa merasa senang dan bangga atas dirinya sehingga dengan sendirinya 
mau belajar dan berlatih bersama teman-teman sebayanya.

Tujuan kegiatan ini dapat dicapai melalui metode presentasi dengan media audio dan video, serta diskusi interaktif. Kemudian pemahaman para remaja dapat dinilai melalui diskusi interaktif dan diskusi kelompok. Kegiatan pengabdian masyarakat ini diharapkan dapat meningkatkan dan mengembangkan potensi yang dimiliki oleh para remaja sehingga mereka dapat membentuk personal branding atas diri mereka sendiri, menumbuhkan rasa kepercayaan diri, mengembangkan ketrampilan komunikasi serta bergaul dengan teman sebayanya khususnya para remaja peserta Youth Camp SOS Children's Village Regional Sumatera di Desa Taruna Meulaboh.

Pemilihan tema dalam kegiatan ini didasari atas pertimbangan bahwa masih kurangnya kesadaran para remaja untuk memanfaatkan potensi media sosial yang mereka miliki sebagai sarana sosialisasi dan menjalin relasi. Mereka cenderung memposting hal-hal random yang justru sama sekali tidak menonjolkan potensi yang mereka miliki. Padahal media sosial memiliki pengaruh besar yang dapat mereka manfaatkan guna menunjang segala aktifitas dan kebuthan mereka. Sehingga diharapkan setelah mendapatkan penjelasan mengenai materi sosialisasi cerdas dan bijak bergaul di era digital ini para remaja tersebut memiliki pengetahuan baru mengenai bagaimana seharusnya cara mereka dalam mengelola dan memanfaatkan media sosial sebagai sarana aktualisasi diri dan mengembangkan potensi yang mereka miliki.

\section{METODE PENELITIAN}

Metode pelaksanaan kegiatan sosialisasi cerdas dan bijak bergaul di era digital ini dilakukan dengan menggunakan pendekatan ceramah dan diskusi interaktif bersama peserta program terkait materi yang disampaikan. Para peserta diberikan materi melalui presentasi visual yang berisikan penjelasan mengenai definisi bergaul, manfaat dan tujuan bergaul, kemampuan yang wajib dimiliki agar mudah bergaul di era digital, cara mengelola media sosial, dan bagaimana menjadi pribadi yang pandai bergaul. Pemberian materi ini dilakukan dengan metode ceramah dengan memanfaatkan laptop dan infocus guna menampilkan power point yang telah dipersiapkan oleh narasumber.

Setelah narasumber memaparkan materinya, peserta dipersilahkan memberikan pertanyaan mengenai materi presentasi. Tanya jawab ini 
berlangsung 15 menit dengan variasi pertanyaan yang berkaitan dengan pengelolaan dan cara membangun branding di media sosial. Kemudian pada akhir kegiatan sosialisasi, peserta dibagi ke dalam 3 kelompok besar dan diberikan sebuah kasus guna dipecahkan bersama temantemannya. Hasil diskusi kelompok tersebut kemudian dipresentasikan oleh salah seorang perwakilan kelompok di depan ruangan agar peserta dari kelompok lain dapat memberikan tanggapan mereka sehingga akan terjadi diskusi interaktif antar kelompok. Pada tahap ini pengetahuan para peserta terhadap materi dapat dinilai dari serangkaian jawaban yang mereka berikan.

Selain sebagai metode evaluasi dari kegiatan sosialisasi ini, diskusi kelompok ini juga merupakan ajang bagi para peserta untuk berinteraksi satu sama lain, dan melatih kerjasama antar anggota kelompok yang mana hal ini merupakan salah satu bentuk nyata dari kegiatan bergaul yang merupakan tema utama dalam kegiatan sosialisasi ini. Sehingga dapat ditarik kesimpulan bahwa setelah mendapatkan penjelasan mengenai cerdas dan bijak bergaul di era digital ini peserta memiliki pengetahuan baru mengenai bagaimana cara mereka dalam mengelola dan memanfaatkan media sosial sebagai sarana aktualisasi diri dan mengembangkan potensi yang mereka miliki.

Adapun yang menjadi sasaran dalam kegiatan ini adalah peserta Youth Camp SOS Regional Sumatera yang merupakan remaja dengan rentang usia 15 sampai 18 tahun yang berasal dari Banda Aceh, Meulaboh, dan Sumatera Utara. Jumlah remaja yang mengikuti kegiatan Youth Camp ini diperkirakan berjumlah 50 orang.

Kegiatan ini dilakukan dengan pemahaman bahwa masih kurangnya kesadaran para remaja untuk memanfaatkan potensi media sosial yang mereka miliki sebagai sarana sosialisasi dan menjalin relasi. Mereka cenderung memposting hal-hal random yang justru sama sekali tidak menonjolkan potensi yang mereka miliki. Padahal media sosial memiliki pengaruh besar yang dapat mereka manfaatkan guna menunjang segala aktifitas dan kebutuhan mereka. 
Sehingga diharapkan setelah mendapatkan penjelasan mengenai materi sosialisasi cerdas dan bijak bergaul di era digital ini para remaja tersebut memiliki pengetahuan baru mengenai bagaimana seharusnya cara mereka dalam mengelola dan memanfaatkan media sosial sebagai sarana aktualisasi diri dan mengembangkan potensi yang mereka miliki. Oleh karena itu, penting untuk diberikannya pembimbingan kepada para remaja peserta Youth Camp SOS Children's Village Regional Sumatera di Desa Taruna Meulaboh guna meningkatkan dan mengembangkan pemahaman mereka mengenai cerdas dan bijak bergaul di era digital melalui pelaksanaan pengabdian masyarakat.

\section{HASIL DAN PEMBAHASAN}

Pelaksanaan kegiatan pengabdian masyarakat secara insidentil dengan tema cerdas dan bijak bergaul di era digital telah dilaksanakan pada hari Jum'at, 28 Juni 2019. Dalam sosialisasi yang dilakukan tersebut, penulis terlibat langsung menjad narasumber utama. Kegiatan sosialisasi merupakan salah satu agenda yang merupakan rangkaian acara Youth Camp SOS Children's Village Regional Sumatera yang dilaksankan di SOS Desa Taruna
Meulaboh. Pelaksanaan kegiatan Youth Camp ini sendiri memiliki tujuan untuk mengembangkan potensi serta bakat yang ada dalam diri para remaja yang diasuh oleh sOS Children's Village yang tersebar di 3 daerah di sumatera yakni Banda Aceh, Meulaboh, dan Sumatera Utara.

Gambar 1. Pemateri tengah melakukan tanya jawab dengan peserta

Adapun materi yang diberikan oleh narasumber meliputi

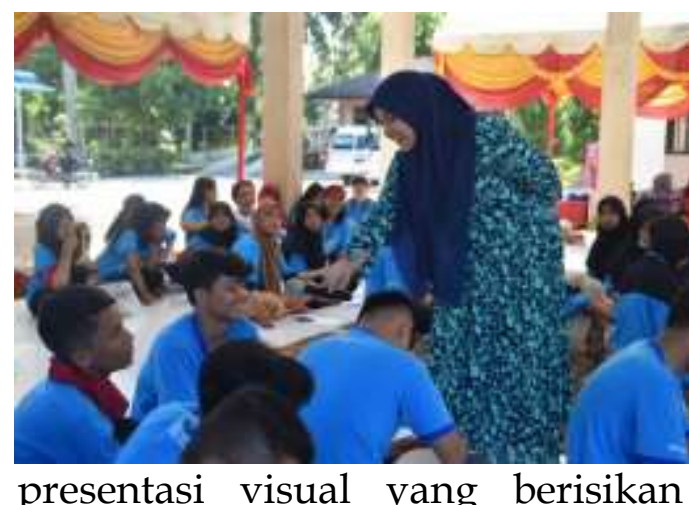

presentasi visual yang berisikan penjelasan mengenai definisi bergaul, manfaat dan tujuan bergaul, kemampuan yang wajib dimiliki agar mudah bergaul di era digital, cara mengelola media sosial, dan bagaimana menjadi pribadi yang pandai bergaul (materi terlampir). Pemberian materi ini dilakukan dengan metode ceramah dengan memanfaatkan laptop dan infocus guna menampilkan power point yang telah dipersiapkan oleh narasumber, kemudian dilanjutkan 
dengan sesi diskusi interaktif dan diskusi kelompok.

Gambar 2. Foto bersama pemateri dan seluruh peserta Youth Camp

Kegiatan sosialisasi yang berlangsung selama 120 menit ini berjalan lancar dan menyenangkan.

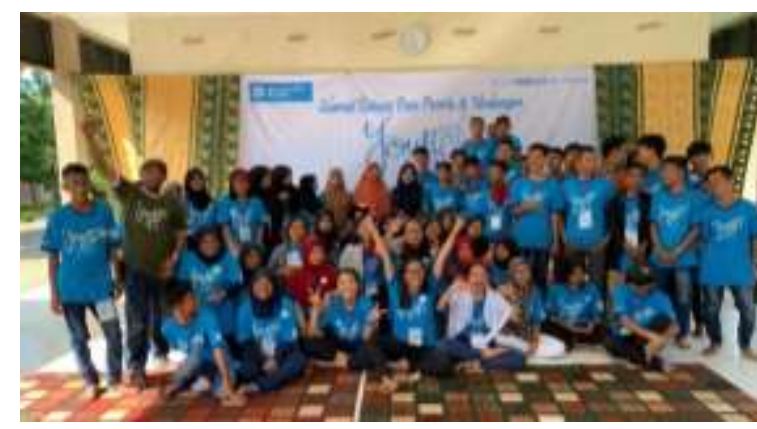

Para peserta sangat antusias dengan tema yang dipaparkan oleh narasumber. Hal ini terlihat dari banyaknya pertanyaan yang mereka berikan pada saat sesi diskusi interaktif diberikan yang meliputi tentang dengan pengelolaan dan cara membangun branding di media sosial.

Sehingga setelah mengikuti sosialisasi dengan pokok pembahasan mengenai Cerdas dan Bijak Bergaul di Era Digital ini para peserta Youth Camp SOS Children's Village Regional Sumatera di Desa Taruna Meulaboh mampu: menerima fisiknya sendiri berikut keragaman kualitasnya; menumbuhkan kepercayaan dan penerimaan atas dirinya; (iii) menemukan role model sebagai acuan pembentukan identitas-nya; (iv) mengembangkan ketframpilan komunikasi interpersonal dan bergaul dengan teman sebaya, baik secara individual maupun kelompok; (v) mengelola dan memanfaatkan media sosial sebagai sarana aktualisasi diri dan mengembangkan potensi yang mereka miliki; and (vi) membangun relasi dan membangun bisnis online yang berdasarkan kemampuan dan minat yang dimilikinya melalui media sosial.

\section{KESIMPULAN}

Di era digital yang menuntut kecepatan dan kemudahan seperti sekarang ini, remaja tidak dapat mengelakkan kemajuan perkembangan media sosial. Media sosial menjadi faktor utama untuk mendapatkan informasi terkini, sarana bersosialisasi dan menjalin relasi, bahkan mampu merubah cara pandang seseorang dalam menyikapi sesuatu yang sedang terjadi. Pergeseran pola interaksi dan sosialisasi ini bahkan mendorong beberapa remaja mulai menjadikan media sosial mereka sebagai sarana bisnis online yang mampu mendulang jutaan rupiah dalam waktu singkat.

Namun tentu saja tidak semua remaja sadar akan peluang dan potensi yang ia miliki atas dirinya. 
Mereka masih memerlukan bimbingan dan arahan dari para orang dewasa guna menemukan role model sebagai acuan pembentukan identitasnya, menumbuhkan kepercayaan dan penerimaan atas dirinya, mengembangkan ketrampilan komunikasi interpersonal dan bergaul dengan teman sebayanya. Pemberian pengetahuan dan pemahaman mengenai personal branding ini tentunya dapat membantu mereka dalam menyiapkan dan meningkatkan daya saing serta kepekaan terhadap tantangan perkembangan zaman yang mengharuskan mereka untuk mampu mengembangkan kemampuan diri, memiliki gagasan cemerlang dengan metode thinking out of the box, memiliki kemampuan berkomunikasi yang baik dengan memanfaatkan media sosial dan internet secara bijak.

\section{DAFTAR PUSTAKA}

Agriati, Siti Hafsah Budi. 2008. Perilaku Agresif Ditinjau dari Persepsi Pola Asuh Authoritarian, Asertivitas dan Tahap Perkembangan Remaja Pada Anak Binaan Lembaga Pemasyarakata Anak Kutoarjo, Jawa Tengah. Tesis.

Ali, Mohammad. 2009. Psikologi Remaja (Perkembangan
Peserta Didik). Jakarta: PT Bumi Aksara.

Doubtire, Dianne. 2004. Teknik Bergaul yang Efektif. Jakarta: Binarupa Aksara.

Jahja, Yudrik. 2011. Psikologi

Perkembangan. Jakarta: Kencana.

Jatmika, Sidik. 2010. Genk Remaja, Anak Haram Sejarah ataukah Korban Globalisasi.

Yogyakarta: Kanisius

Mappiare, A. 2000. Psikologi Remaja. Surabaya: Bina Usaha.

Monks, F.J. dan AMP Roney. 2006. Psikologi Perkembangan: Pengantar dalam Berbagai Bagian. Yogyakarta: Gadjah Mada University Press.

Putro, Khamim Zarkasih. 2017. Memahami Ciri dan Tugas Perkembangan Masa Remaja. Jurnal Aplikasi Ilmuilmu Agama. UIN Sunan Kalijaga. Vol 17 No 1

Ruslan, Rosady. 2008. Etika Kehumasan Konsepsi $\mathcal{E}$ Aplikasi. Jakarta: PT Raja Grafindo Persada.

Ruslan, Rosady. 2008. Etika Kehumasan Konsepsi $\mathcal{E}$ Aplikasi. Jakarta: PT Raja Grafindo Persada. 
Jurnal Pengabdian Masyarakat: Darma Bakti Teuku Umar Fakultas Ilmu Sosial dan Ilmu Politik

Santrock. 2003. Adolescence. Jakarta: Erlangga

Wirawan, S. 2002. Psikologi Remaja, Jakarta: Raja Grafindo Persada
Vol 1, No 1 (2019) Juli-Desember darmabakti@utu.ac.id 